\title{
Review
}

\section{We created Chávez: A people's history of the Venezuelan revolution}

\author{
George Ciccariello-Maher \\ Duke University Press, Durham, NC, 2013, xi+320 pp., ISBN: 978-0-8223-5439-0
}

Contemporary Political Theory (2015) 14, e208-e211. doi:10.1057/cpt.2014.20;

published online 11 November 2014

George Ciccariello-Maher's 'We Created Chávez: A People's History of the Venezuelan Revolution' is an impressive work that locates the Bolivarian Revolution, not directly in the figure of Hugo Chávez, but rather in Venezuela's diverse and vibrant social movements, whose activities made Chávez's rise to power possible. The book is loyal to its subtitle in terms of content and method. Ciccariello-Maher situates himself not as a neutral outside observer mining Venezuelan social movements for data to prove or disprove a particular theoretical paradigm, but rather as someone who speaks to those about whom he writes and who finds in these conversations important theoretical reflections on the relationship between state and society in Venezuela and revolutionary struggles.

The book begins on the ground with a meeting of the author in a Caracas barrio with the historic leader of the revolutionary collective La Piedrita, which, like many of Venezuela's collectives, has a history reaching back before Chávez's election and which 'began as a spontaneous community response to the scourge of narcotrafficking, as young revolutionaries - imbued with the history and ideology of struggles past confronted both the drug trade and the violently corrupt state that facilitated it' (p. 3). It is from this encounter that Ciccariello-Maher draws the paradox driving the rest of the book. How is it, he asks, 'that the vast majority of such militants [from collectives like La Piedrita] - those who deeply despise corruption, bureaucracy, and even the state itself and are more likely to associate the state with torture, murder, and 'disappearance' - are still Chávistas, at least for the time being' (p. 5). Without these militant groups, he argues, Chávez would not have arrived at nor remained in power. Their key role is lost to those accounts on both right and left that fetishize either state power (that is, it's all Chávez) or conversely anti-state power and horizontalism (that is, the only true revolutionary movements are those that oppose the state or have no interest in state power). To write a people's history of the Venezuelan Revolution, insists CiccarielloMaher, one must instead see how the 'multiplicity of revolutionary social movements' to which the initial post-1958 guerilla struggle gave way lent their support and loyalty 
to Chávez, but, importantly, always temporarily and contingently. For the author, the struggle thus begins, rather than ends, with the establishment in 1958 of a formal democracy that was later consolidated into an anti-popular two-party system known as puntofijismo, "in which the people could only appear as a fragmentary and segmented nonpeople" (p. 10).

Focusing on the relationship between the state and Venezuela's revolutionary social movements makes the history of the revolution look different. Whereas a purely state-centered approach highlights the taking of power or failure to do so (Chávez's failed coup in 1992 or his election in 1998), Ciccariello-Maher's approach brings two other moments to the fore: the Caracazo of 1989, when 'the people', and specifically the lumpenproletariat (a term the author reappropriates as positive and revolutionary) took to the streets to protest the structural reform package of Carlos Andrés Pérez; and the 2002 countercoup, when the people took to the streets again to protest the coup against Chávez and demand his return to office. Both moments, argues the author, functioned to highlight and clarify long-standing conflicts, and to illustrate that Chavez's existence and survival depended upon "the people" (el pueblo), understood as a "category of both rupture and struggle," rather than of unity (p. 8). The moments pointed to the limits of a strain of vanguardism, which existed within organized social movements in Venezuela, and to the ways that the people themselves were the catalyst for change. In this sense, this people's history is not about adding the people to the grand narrative of Chávez's rise to power (state fetishism or the big man theory of revolution), but about pointing to the struggle from below, including the struggle over who the people are, and to the complicated ways that these movements have not just negotiated with the state, but also transformed it. Ciccariello-Maher appropriates and expands upon Lenin's concept of 'dual power', to describe alternative government structures and popular power not necessarily in opposition to the traditional state structure (with the aim of taking over that state), but rather as 'a fulcrum to radically transform and deconstruct' that state (p. 240). This dual power is exemplified in the armed self defense militias and selfgoverning barrio assemblies, both of which 'emerged organically from the ashes of past failures' (p. 241).

The book is not just history from the ground up, but also political theory from the ground up. It is never dominated by a general theory of revolution, of social change, or of state/society relations. Cicarriello-Maher is critical of the ways that European theorists translate the experience of Latin American revolution, usually incorrectly or insufficiently. He is clear that he does not wish to be another Regis Debray, whose caricatured analysis of the Cuban revolution, he argues, led to an overemphasis on foquismo that contributed to a tendency toward vanguardismo among the revolutionary social movements in Venezuela. Instead, theory emerges from the history he tells. In this sense, the book falls within the tradition of several of the works the author cites. Like C.L.R. James's The Black Jacobins, Frantz Fanon's The Wretched of the Earth and José Carlos Mariátegui's Seven Interpretive Essays on Peruvian 
Reality, the book teases theory out of the experiences of political struggle. It draws upon theoretical reflections derived from other historical experiences because they help to illuminate that which has been overlooked or discarded, rather than treating theory as universal doctrine that bookends analysis, proven or disproven by the facts.

We Created Chavez locates the source of theoretical reflections in the political actors themselves. The book covers a wide range of social movements and struggles in Venezuela including those of students, women, Afro-Venezuelans, indigenous peoples, workers, peasants, and informal labor. It traces the development of and tensions within these individual movements, their relationships with one another and with the state. A key fact that emerges from this close attention to the social movements' struggles on the ground is that they often joined, rather than led, moments like the Caracazo and the resistance to the coup. The book sometimes seems to take a bird's eye view, assessing social movement's failures in terms of vanguardism and at other times as failures of history itself (the time wasn't right). While specific events may have catalyzed the people to action, with the organized social movements following behind, the reader is left wondering at times about the contributions of specific strategies and issues of these social movements to the unity of "the people" and about the specific role of Chávez in the process? Could any leader have played the role that Chávez played?

The author's argument seems to be that the most successful organized social movements did not lead, but were led by, the people. However, it is not always clear that the members of these movements saw themselves in the role of the rearguard, rather than the vanguard. Also, the book provides numerous examples of Venezuelan activists clearly stating their strategic relationship to the state, but there are fewer examples of the state or its representatives articulating a more nuanced relationship. For instance, how did Chávez and other members of his government view their own relationship to the state institutions and social movements? Did they too see popular support as contingent and temporary? Did they see themselves as representatives of obediential power, a term Ciccariello-Maher draws from the work of Enrique Dussel to refer to power constantly flowing from the people and responsible to them? Of course, as Ciccariello-Maher notes, it is 'always difficult to distinguish the rhetoric of a political leader from the depth of his or her understanding of the situation' (p. 254). That the reader now finds herself asking such questions is evidence of how successfully the book shifts the terms of the discussion opening up new avenues not just for praise of the process, but for critique as well.

The resistance to fetishizing state power or anti-state power is valuable for thinking about other contexts, such as Cuba, where state/society dynamics are often reduced to stories of either coercion and co-optation or resistance and autonomy from the state. In this sense, the book is a wonderful contribution to breaking stale discussions of state/society relations in revolutionary contexts and should be required reading, not just for students of Venezuela, but also for those of revolutionary 
societies more generally. The book also shows us that comparative political theory need not be limited to the comparison of political theorists from different parts of the world, but can also include the study of how political thought is mobilized and produced by social movements.

Katherine A. Gordy San Francisco State University, San Francisco, CA 94132, USA email: kgordy@sfsu.edu 